\title{
Foliar application of polyamines improve some morphological and physiological characteristics of rose
}

\author{
Fereshteh Yousefi, Zohreh Jabbarzadeh ${ }^{1, *}$, Jafar Amiri', \\ MirHassan Rasouli-Sadaghiani', Ali Shaygan ${ }^{3}$
}

\footnotetext{
${ }^{1}$ Department of Horticultural Science, Faculty of Agriculture, Urmia University, Urmia, Iran ${ }^{2}$ Department of Soil Science, Faculty of Agriculture, Urmia University, Urmia, Iran ${ }^{3}$ Department of Plant Production, Parks and Landscape Organization of Urmia, Urmia, Iran
}

\begin{abstract}
Objective: This experiment was conducted to investigate the effects of foliar spray of polyamines on some morphological and physiological characteristics of rose.

Materials and methods: Experimental variants involved the type (putrescine, spermidine and spermine) and concentration $(0 \mathrm{mM}, 1 \mathrm{mM}, 2 \mathrm{mM}$ and $4 \mathrm{mM})$ of polyamines. In this research, the plant height, number of leaves and shoots, leaf area and thickness, fresh and dry weight of leaf and stem, the content of anthocyanin, soluble sugar, phenol and antioxidant capacity were measured 2 weeks after the end of experiment.

Results: Results indicated that among all polyamine types, putrescine has the highest effect on the morphological characteristics. Among different concentrations of polyamines, the concentration of $1 \mathrm{mM}$ resulted in the highest increase in shoot fresh and dry weight. Putrescine application at $2 \mathrm{mM}$ and $4 \mathrm{mM}$ concentrations increased soluble sugar content. In the present study, polyamine treatment reduced the content of anthocyanin, phenol and antioxidant capacity.

Conclusions: It can be cocluded that application of polyamines improved some morphological and physiological traits in various ways.
\end{abstract}

Keywords: antioxidant capacity, anthocyanin, growth characteristics, putrescine, spermidine, spermine

\section{INTRODUCTION}

Rose belongs to the family Rosaceae and the genus Rosa includes more than 100 different species. Roses can also be grown as pot plants, and some of their varieties are suitable for cultivation in rock gardens or hanging baskets. They have been cultivated as cut flowers in addition to their garden use, in different parts of the world. The optimum night temperature for rose is between $13.3^{\circ} \mathrm{C}$ and $20^{\circ} \mathrm{C}$, and the optimum day temperature is in the range of $20-28^{\circ} \mathrm{C}$. Temperatures $<13^{\circ} \mathrm{C}$ and $>30^{\circ} \mathrm{C}$ impair the production and quality of flowers. Sandy loamy, loamy or slightly clay soils with
$10 \%$ organic matter are suitable for roses. The optimum $\mathrm{pH}$ for roses is about 6.5; however, the $\mathrm{pH}$ between 5.5 and 7.5 is also suitable (Bhattacharjee and Banerji, 2010).

Polyamines are aliphatic hydrocarbons that have a low molecular weight, a straight chain of 3-15 carbon atoms and two terminal amino groups, and in many cases, they have one or more amine groups (AsnaAshari and Zokai-Khosroshahi, 2008). Putrescine, spermidine and spermine are the most commonly found polyamines in higher organisms (Pegg and Michael,

\footnotetext{
*Corresponding author.

e-mail: z.jabbarzadeh@urmia.ac.ir (Zohreh Jabbarzadeh).
} 
2010). Putrescine and spermidine are present in all living cells, while spermine is present in eukaryotes and some bacteria (Pegg and Michael, 2010). Polyamines have important effects on physiological processes of plants such as gene expression, protein and DNA synthesis, cell division and differentiation, growth and developmental processes such as somatic embryogenesis, organogenesis, breaking dormancy of tubers, seed germination, flower initiation and development, fruit development and ripening, root growth, senescence and responses to biotic and abiotic stresses (Alcazar et al., 2010; Amorim et al., 2017; Mustafavi et al., 2018) and control of nitrogen to carbon balance (Wang et al., 2019). Polyamines bind to negatively charged molecules such as nucleic acids, proteins and phospholipids by ionic bonds and hydrogenase; thus, polyamines and inhibitors of polyamine synthesis can regulate the nucleic acid synthesis and protein translation (Chen et al., 2019). Carbon and nitrogen are very important for plant growth and development and response to stress. Polyamines and several other N-rich metabolites play a physiologically important role in the assimilation and balancing of the nitrogen to carbon ratio and thus plant growth and response to stress (Mustafavi et al., 2018). Studies have shown that the increase in the amount of endogenous polyamine can alter the gene expression level of genes involved in the synthesis and signalling of plant hormones such as abscisic acid (ABA), auxin, ethylene (Eth), gibberellins (GAs) and jasmonic acid (JA) (Tajti et al., 2019). It has been shown that plant hormones in plant growth and development are associated with the metabolism of polyamines. Changes in the amount of polyamine and their biosynthetic enzymes are associated with many hormonal responses, and in a few cases, polyamine seems to mimic the effects of plant hormones (Mustafavi et al., 2018). For example, ABA is an essential phytohormone that plays an important role in responding to abiotic stress and stress signalling. Reports suggest a positive interaction between putrescine and ABA that stimulates each other's biosynthesis in regulating abiotic stress responses (Alcazar et al., 2010). Polyamines also have positive feedback with GA (Anwar et al., 2015). Auxin is another hormone that has crosstalk with polyamines. Tissues treated with auxin showed an increase in polyamine levels before cell division and other morphological changes. Polyamines have a strong relation with Eth. S-adenosylmethionine (SAM) is a precursor to the biosynthesis of both polyamines and Eth. Thus, they compete with each other for SAM. Jasmonates are a group of signalling molecules that play a key role in regulating polyamine biosynthesis (Mustafavi et al., 2018). In a study on the effect of humic acid and putrescine on rose, it was reported that humic acid with putrescine increased stem fresh and dry weight, leaf area and plant height (Dastyaran and Hosseini-Farahi, 2014). In Dahlia pinnata, leaf spraying with putrescine and thiamine showed that putrescine treatment significantly increased plant height, number of shoots, number of leaves, leaf fresh and dry weight, stem diameter and stem fresh and dry weight (Mahgoub et al., 2011). In Antirrhinum majus, foliar putrescine spray led to increases in parameters such as plant height, number of shoots, number of leaves, leaf area and stem fresh and dry weight (Badawy et al., 2015a). The effect of putrescine and salinity on Calendula officinalis demonstrated that putrescine increases the soluble sugar of leaves (Bani-Assadi et al., 2015). In another research focused on the effect of putrescine and uniconazole on Salvia splendens, the results showed that putrescine had increased anthocyanin and soluble sugar content (Kandil et al., 2015). In Celosia argentea, foliar application of putrescine with alpha-tocopherol showed that anthocyanin of inflorescences and total carbohydrates of shoots and inflorescences were significantly increased compared to the control (Badawy et al., 2015b). Spraying of Alstroemeria aurantica cv. Sukari with putrescine and spermine in two stages, i.e. before and after harvest, increased the activity of the catalase enzyme. Putrescine and spermine reduced the activity of leaf chlorophyllase enzymes and flower pectinase and phenoloxidase (Alborz et al., 2015).

Based on the literature cited, polyamines are closely related to physiological processes such as organogenesis and plant growth and development. In accordance with the above, this study aimed to evaluate the effect of different concentrations of three polyamines, i.e. putrescine, spermidine and spermine, on some growth and developmental traits of rose bushes cv. 'Herbert Stevens' under non-stress conditions.

\section{MATERIALS AND METHODS}

\section{Plants materials and treatments}

To investigate the effect of polyamines on some morphological and physiological characteristics of roses (Rosa hybrida 'Herbert Stevens'), a factorial experiment was conducted in a completely randomised design with two factors including type of polyamine (putrescine, spermidine and spermine (Sigma-Aldrich)) and concentration of polyamine $(0 \mathrm{mM}$ (control), $1 \mathrm{mM}$, $2 \mathrm{mM}$ and $4 \mathrm{mM}$ ) with three replications. Each replication included two pots, and each pot was composed of one single plant. The potted roses were treated with foliar application of the polyamine every 14 days for 2 months.

\section{Growing conditions}

This research was carried out in the greenhouse of Parks and Landscapes Organization of Urmia and the research laboratories of the Departments of Horticultural and Soil Science, Faculty of Agriculture, Urmia University. To perform this research, cuttings were prepared from the mother plants and planted in a bed containing sand for rooting. After rooting, they were transferred to separate pots (plastic pots with a diameter of $14 \mathrm{~cm}$ and a height of $11 \mathrm{~cm}$ ) and given two months for new plants to be fully established. After establishment, they were 
prepared for polyamine treatments. The greenhouse day/night temperature was set at $28-30^{\circ} \mathrm{C} / 20-23^{\circ} \mathrm{C}$. The soil used in the pots was composed of garden soil and sand $(3: 1 \mathrm{v} / \mathrm{v})$.

\section{Biometric measurements}

Two weeks after the final treatment, the morphological parameters were measured. They included plant height, number of leaves, number of shoots, leaf area, leaf thickness and fresh and dry weight of leaves and stems. To measure the effect of polyamines on the plant height and the number of leaves, the difference between the plant height and the number of leaves was examined in two periods. Therefore, they were once measured before the start of treatments, and then, 14 days later (after the end of treatments), they were measured again to achieve a rigorous measurement for the amount of the increase in the plant height and the number of leaves. The number of shoots per plant was counted. The leaf area was measured with a Leaf Area Meter (AM-200, ADC Bioscientific Ltd. UK), leaf thickness was estimated with a micrometer (MDC-COSB model, Mitutoyo products, Japan), and fresh and dry weight of leaf and stem was determined with a digital scale $(0.0001 \mathrm{~g})$.

\section{Biochemical analyses}

Biochemical characteristics including anthocyanins, soluble sugar, phenol and antioxidant capacity were recorded.

Anthocyanin level was measured with Wagner's (1979) procedure. Leaf samples (0.1 g) were soaked in $10 \mathrm{ml}$ acidified methanol [methanol: $\mathrm{HCl}$ 99:1 v/v]. The extracts were centrifuged at 4,000 rpm for $5 \mathrm{~min}$. The absorption rate of the supernatant was read by a spectrophotometer at $550 \mathrm{~nm}$.

Soluble sugar was evaluated by following Irigoyen's et al. (1992) procedure with some modification. A quantity of $0.5 \mathrm{~g}$ of the fresh leaf was crushed with $5 \mathrm{ml}$ of ethanol (70\%) and the mixture was centrifuged $\left(3,500 \mathrm{rpm}\right.$ for $15 \mathrm{~min}$. at $\left.4^{\circ} \mathrm{C}\right)$. A quantity of $3 \mathrm{ml}$ of anthrone $(0.2 \%)$ was added to $0.1 \mathrm{ml}$ of the obtained supernatant. Total soluble sugar content was determined using a spectrophotometer at $625 \mathrm{~nm}$.

Total phenol was determined according to Marinova's et al. (2005) method. A quantity of $1 \mathrm{ml}$ of the leaf extract was mixed with $9 \mathrm{ml}$ of distilled water, $1 \mathrm{ml}$ of FolinCiocalteu's phenol reagent and $10 \mathrm{ml}$ of $\mathrm{Na}_{2} \mathrm{CO}_{3}(7 \%)$ in three-step. Absorbance was characterised at $750 \mathrm{~nm}$.

Antioxidant activity was measured by the 2,2-diphenyl-1-picrylhydrazyl (DPPH) radical degradation method (Espin et al., 2000) with slight modifications. A quantity of $1,000 \mu \mathrm{l}$ of DPPH solution $(0.1 \mathrm{mM})$ was added to $50 \mu \mathrm{l}$ of leaf extract solution and after $50 \mathrm{~min}$ the absorbance was measured at $517 \mathrm{~nm}$.

Finally, the SAS software package (version 9.1) was used for data analysis and means of the tested traits were compared using Duncan's Multiple Range Test at $p=0.01$ and $p=0.05$.

\section{RESULTS AND DISCUSSIONS}

\section{Morphological characteristics}

Data presented in the Table 1 indicated that, among different concentrations of polyamines, only putrescine at the concentration of $1 \mathrm{mM}$ significantly increased plant height $(16.6 \mathrm{~cm})$ as compared to the control plants $(7.6 \mathrm{~cm})$; however, there is no significant difference between concentrations of putrescine $(1 \mathrm{mM}, 2 \mathrm{mM}$ and $4 \mathrm{mM})$. Furthermore, except putrescine $(1 \mathrm{mM})$, there was no notable plant height variance at all.

Putrescine treatment $(1 \mathrm{mM})$ has significantly increased the number of shoots (6.3 of shoots/plant) in comparison with the control plants. However, other polyamine treatments (put $2 \mathrm{mM}$ and $4 \mathrm{mM}$, spd 1, $2 \mathrm{mM}$ and $4 \mathrm{mM}$, spm 1, $2 \mathrm{mM}$ and $4 \mathrm{mM}$ ) did not lead to any significant difference compared to the control plants (see Table 1).

With respect to the fresh and dry weight of stems of plants, it can also be observed that among all levels of polyamines, only spermine at the concentration of $1 \mathrm{mM}$ was related to the highest fresh (16.5 g) and dry weight (8.4 g), while other concentrations of polyamines did not differ significantly with untreated plants (Figures 1 and 2). These results are in agreement with those reported by Dastyaran and Hosseini-Farahi (2014) on Rosa, El-Quesni et al. (2007) on Bougainvillea glabra, Mahgoub et al. (2011) on Dahlia pinnata and Badawy et al. (2015a) on Antirrhinum majus. These studies have indicated that putrescine has been involved in a wide range of growth developmental processes including plant height, shoot length, leaf number and fresh and dry weight of the plants.

Polyamines are recognised as a new class of plant growth bioregulators causing in-plant growth. Plants' growth rate directly depends on the content of endogenous polyamines, and the cessation of the biosynthesis of these substances slows down or even stops plant growth. The results obtained from the mutated species that were not capable of producing polyamines have shown that the application of specific amounts of polyamines nullifies these inhibitory effects and restores their healthy growth. Stem growth can be attributed to the increasing activity of cell division (Asna-Ashari and Zokai-Khosroshahi, 2008). Studies have shown that the increase in plants' putrescine levels will lead to their higher cell division activity (ElQuesni et al., 2007). Auxin and GA are involved in cell and stem growth (Kusano and Suzuki, 2015). Several studies have reported the direct relationship between polyamines and auxin and GA (Asna-Ashari and ZokaiKhosroshahi, 2008). Probably, within the present study, polyamines - putrescine, in particular - have stimulated the growth, cells division, plant height and the number of shoots by affecting auxin and GA, and all these qualities represent the increased plant biomass. According to the increased level of plant height, putrescine has a more significant effect on vegetative growth than spermine and spermidine. 
Table 1. The effect of putrescine (Put), spermidine (Spd) and spermine (Spm) on some characteristics of rose 'Herbert Stevens'.

\begin{tabular}{llccccc}
\hline Treatment & $\begin{array}{l}\text { Leaves dry } \\
\text { weight }(\mathrm{g})\end{array}$ & $\begin{array}{c}\text { Leaves fresh } \\
\text { weight }(\mathrm{g})\end{array}$ & $\begin{array}{c}\text { Leaf area } \\
\left(\mathrm{mm}^{2}\right)\end{array}$ & $\begin{array}{c}\text { Number of leaves/ } \\
\text { plant }\end{array}$ & $\begin{array}{c}\text { Number of } \\
\text { shoots/plant }\end{array}$ & $\begin{array}{c}\text { Plant height } \\
(\mathrm{cm})\end{array}$ \\
\hline Control & $0.18 \pm 0.03 \mathrm{c}$ & $0.44 \pm 0.07 \mathrm{~cd}$ & $2,604 \pm 174.45 \mathrm{bc}$ & $19.60 \pm 0.58 \mathrm{ab}$ & $4.30 \pm 1.53 \mathrm{~b}$ & $7.60 \pm 1.16 \mathrm{bc}$ \\
Put 1 mM & $0.31 \pm 0.03 \mathrm{a}$ & $0.71 \pm 0.04 \mathrm{a}$ & $3,371 \pm 235.56 \mathrm{a}$ & $22.60 \pm 3.06 \mathrm{a}$ & $6.30 \pm 1.53 \mathrm{a}$ & $16.60 \pm 3.21 \mathrm{a}$ \\
Put 2 mM & $0.30 \pm 0.03 \mathrm{a}$ & $0.72 \pm 0.06 \mathrm{a}$ & $3,624 \pm 395.18 \mathrm{a}$ & $14.60 \pm 1.53 \mathrm{bc}$ & $3.60 \pm 1.15 \mathrm{~b}$ & $13.00 \pm 4.36 \mathrm{ab}$ \\
Put 4 mM & $0.28 \pm 0.05 \mathrm{ab}$ & $0.64 \pm 0.09 \mathrm{ab}$ & $3,686 \pm 339.37 \mathrm{a}$ & $18.30 \pm 1.53 \mathrm{abc}$ & $4.30 \pm 0.58 \mathrm{~b}$ & $11.60 \pm 1.53 \mathrm{abc}$ \\
Spd 1 mM & $0.15 \pm 0.03 \mathrm{c}$ & $0.39 \pm 0.06 \mathrm{~d}$ & $2,285 \pm 304.91 \mathrm{c}$ & $18.00 \pm 2.65 \mathrm{abc}$ & $4.30 \pm 0.58 \mathrm{~b}$ & $10.00 \pm 1.73 \mathrm{bc}$ \\
Spd 2 mM & $0.22 \pm 0.02 \mathrm{bc}$ & $0.55 \pm 0.08 \mathrm{bc}$ & $3,275 \pm 322.75 \mathrm{ab}$ & $14.30 \pm 2.52 \mathrm{c}$ & $3.60 \pm 1.53 \mathrm{~b}$ & $6.30 \pm 1.53 \mathrm{c}$ \\
Spd 4 mM & $0.16 \pm 0.012 \mathrm{c}$ & $0.42 \pm 0.07 \mathrm{~cd}$ & $2,649 \pm 330.73 \mathrm{bc}$ & $22.00 \pm 1.00 \mathrm{a}$ & $4.60 \pm 1.53 \mathrm{~b}$ & $9.00 \pm 2.00 \mathrm{bc}$ \\
Spm 1 mM & $0.18 \pm 0.04 \mathrm{c}$ & $0.45 \pm 0.09 \mathrm{~cd}$ & $2,357 \pm 270.19 \mathrm{c}$ & $16.60 \pm 2.08 \mathrm{bc}$ & $3.60 \pm 1.15 \mathrm{~b}$ & $7.60 \pm 1.53 \mathrm{bc}$ \\
Spm 2 mM & $0.23 \pm 0.04 \mathrm{abc}$ & $0.56 \pm 0.11 \mathrm{bc}$ & $3,380 \pm 76.81 \mathrm{a}$ & $15.00 \pm 3.46 \mathrm{bc}$ & $3.60 \pm 0.58 \mathrm{~b}$ & $12.00 \pm 2.00 \mathrm{ab}$ \\
Spm 4 mM & $0.22 \pm 0.03 \mathrm{bc}$ & $0.55 \pm 0.06 \mathrm{bc}$ & $3,435 \pm 329.13 \mathrm{a}$ & $6.60 \pm 2.08 \mathrm{~d}$ & $3.60 \pm 1.15 \mathrm{~b}$ & $9.30 \pm 1.53 \mathrm{bc}$ \\
\hline
\end{tabular}

In each column, values followed by the same letter(s) do not differ significantly $(p=0.01$ and $p=0.05)$.

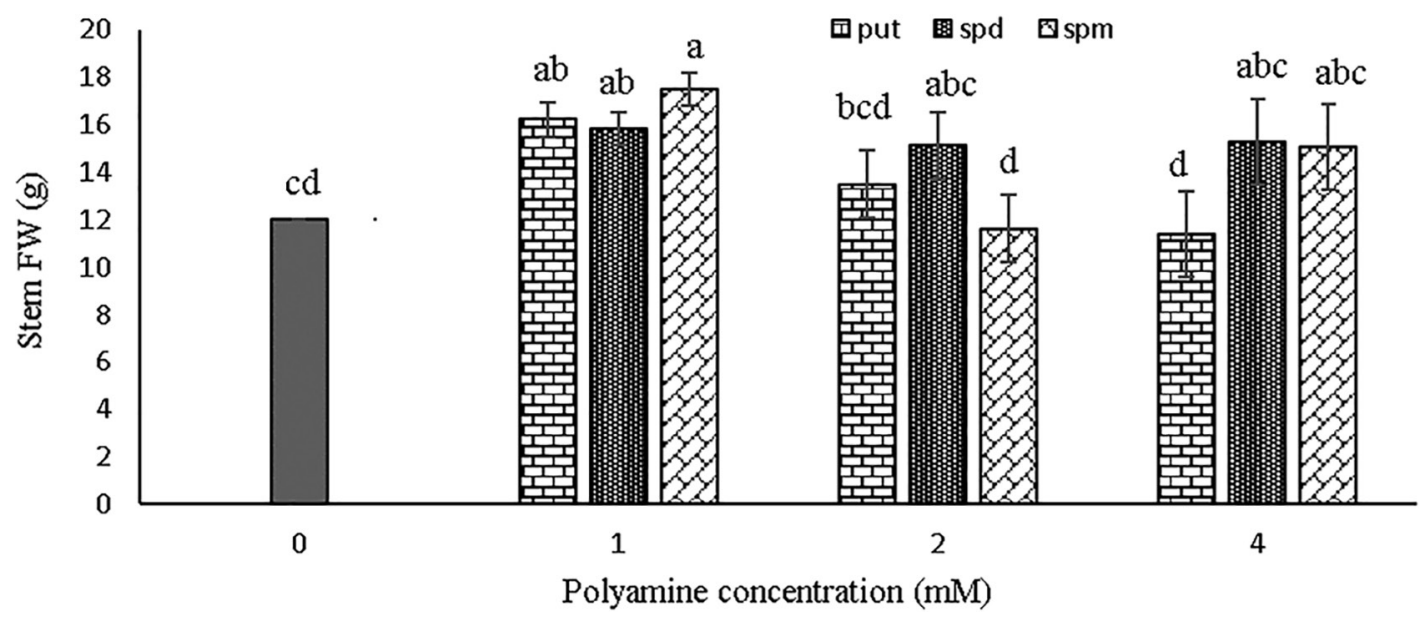

Figure 1. The effect of polyamine concentration on stem fresh weight of rose 'Herbert Stevens'. Values followed by the same letter(s) do not differ significantly at $p=0.01$.

Analysing the value of leaf number under the conditions of present study, the highest increase in the number of leaves was observed in the plants treated with $1 \mathrm{mM}$ putrescine or $4 \mathrm{mM}$ spermidine, but there was no significant difference between other treatments and the control plants. Spermine at the concentration of $4 \mathrm{mM}$ resulted in the lowest number of leaves (see Table 1).

In plants, polyamines are necessary for physiological processes such as organogenesis, embryogenesis, flower initiation and development, leaf aging, pollen tube growth, fruit development and response to biotic and abiotic stresses (Kusano and Suzuki, 2015). The amount of polyamines and their biosynthetic enzymes activity is very high in growing tissues. When growth and differentiation are induced in the cell, the biosynthetic pathways of polyamines are activated, and their concentration increases. Activating the biosynthesis of polyamines usually occurs before the activation of the synthesis of DNA, RNA and protein, and the physiological concentrations of polyamines stimulate many of the reactions involved in the synthesis of nucleic acids and proteins. These findings indicate the role of polyamines in cell growth and differentiation (AsnaAshari and Zokai-Khosroshahi, 2008). As observed in the present study, polyamines increased plant height, the 
number of stems and the number of leaves; so, in other words, polyamines affect growth and cell differentiation.

An increase in leaf number resulting from exogenous polyamines was found by Mahgoub et al. (2011), who investigated the effect of putrescine on growth characteristics of Dahlia pinnata. It has been reported that polyamines have stimulation effects on producing more leaves of Populus euramericana (Habba et al., 2016) and Antirrhinum majus (Badawy et al., 2015a). As seen in different plant species, polyamines have different effects. Although the present study addressed only Rosa hybrida 'Herbert Stevens', we observed different impacts of the type and concentration of polyamines on morphological characteristics.

Regarding the effects of different concentrations of polyamines on the leaf area of rose plants, data revealed (see Table 1) that the increment of leaf area resulting from treatments of putrescine ( $1 \mathrm{mM}, 2 \mathrm{mM}$ and $4 \mathrm{mM}$ ) and spermine ( $2 \mathrm{mM}$ and $4 \mathrm{mM}$ ) were remarkably different in comparison with the control plants. Putrescine at the concentration of $4 \mathrm{mM}$ showed the highest leaf area $\left(3,686 \mathrm{~mm}^{2}\right)$, but it had no significant difference when compared with putrescine (1 $\mathrm{mM}$ and $2 \mathrm{mM}$ ) and spermine ( $2 \mathrm{mM}$ and $4 \mathrm{mM}$ ). The other polyamine treatments did not show any significant difference when compared with the control plants. The minimum leaf area was due to spermidine treatment at the concentration of $1 \mathrm{mM}\left(2,285 \mathrm{~mm}^{2}\right)$, which does not significantly differ from spermidine at the concentration of $4 \mathrm{mM}$, spermine at the concentration of $1 \mathrm{mM}$ and the control plants.

The leaf thickness measurements (Figure 3) allow us to conclude that merely spermidine $(4 \mathrm{mM})$ and spermine $(1 \mathrm{mM})$ have made notable differences from control plants, and no leaf thickness increase was found for polyamine (putrescine, spermidine and spermine) treatments with any concentrations $(1 \mathrm{mM}, 2 \mathrm{mM}$ and $4 \mathrm{mM}$ ) in analogy with the control plant.

According to the Table 1, there was a significant difference in fresh and dry weight of leaves between putrescine and the control, and also spermidine and spermine treated plants. The lowest fresh weight was related to spermidine at the concentration of $1 \mathrm{mM}(0.39 \mathrm{~g})$, and the highest fresh weight was observed in putrescine at the

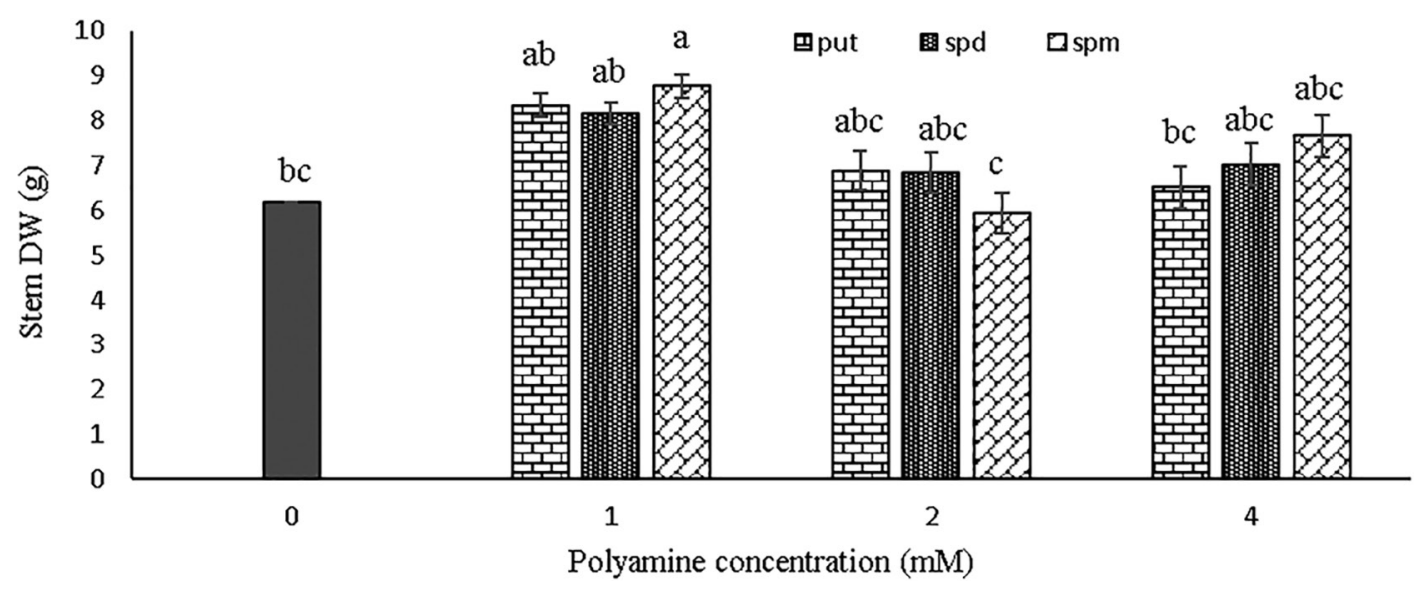

Figure 2. The effect of polyamine concentration on stem dry weight of rose 'Herbert Stevens'. Values followed by the same letter(s) do not differ significantly at $p=0.01$.

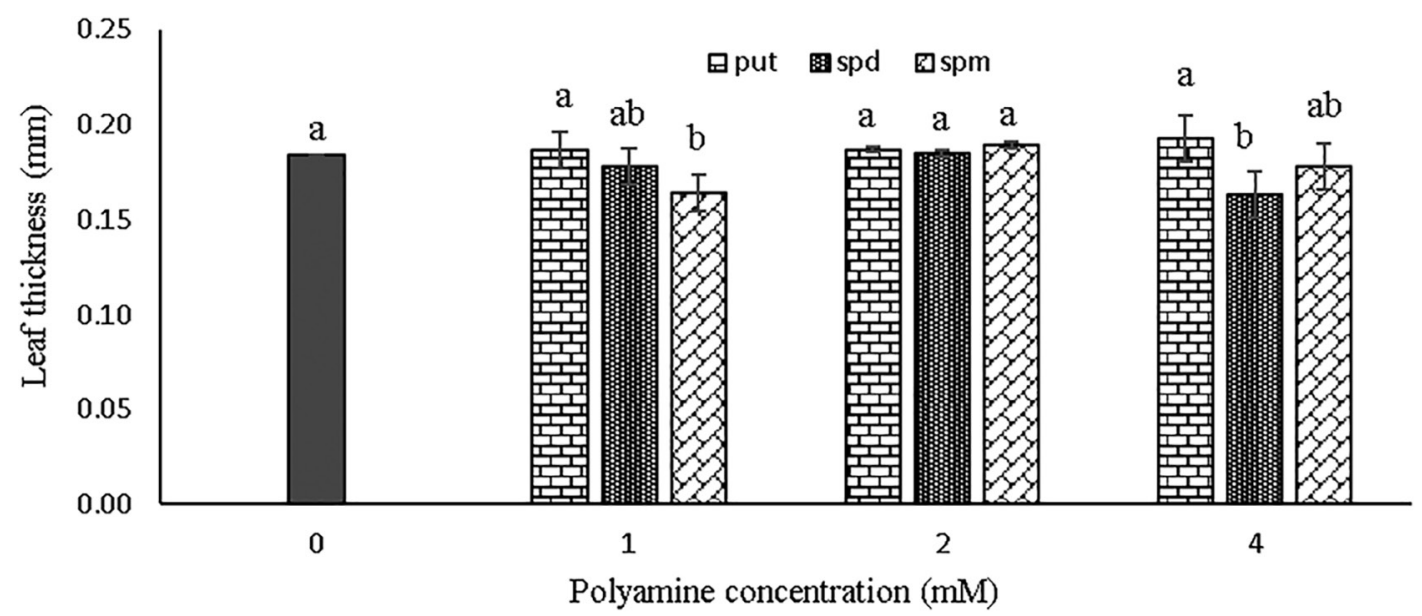

Figure 3. The effect of polyamine type on leaf thickness of rose 'Herbert Stevens'. Values followed by the same letter(s) do not differ significantly at $p=0.05$. 
concentration of $2 \mathrm{mM}(0.725 \mathrm{~g})$. The highest dry weight was observed in plants treated with $1 \mathrm{mM}$ putrescine $(0.314 \mathrm{~g})$, and the lowest dry weight was obtained from those treated with $1 \mathrm{mM}$ spermidine $(0.155 \mathrm{~g})$.

Leaf development is one of the processes influenced by GA and cytokinin (Kusano and Suzuki, 2015). As mentioned, polyamines likely increase leaf area via influencing cell division, thereby increasing the number of cells as well as leaf fresh and dry weight. Polyamines may likely indirectly affect the size and thickness of leaves by affecting cytokinins. The effect of polyamines on growth regulators is different among various plant species. Since both polyamines and cytokinins increase cell division, it is likely that polyamines may have this effect through cytokinins. However, polyamines have a direct relationship with auxins and may also affect leaf size through auxin.

In accordance with these results, in Dahlia pinnata, putrescine increased leaf fresh and dry weight (Mahgoub et al., 2011). The application of putrescine increased the leaf area in Antirrhinum majus. It is argued that the effect of polyamines on growth was due to their effect on increasing cell division and cell development. Moreover, polyamines act as a source of nitrogen and stimulate growth (Badawy et al., 2015a). In Populus euramericana, Habba et al. (2016), reported that putrescine at the concentration of $50 \mathrm{ppm}$ had the highest effect on leaf area and leaf fresh and dry weight.

\section{Biological substance in plant}

Data indicates that the spraying of polyamines increased the amount of soluble sugar in plant leaves (see Figure 4). There is a significant difference between putrescine treatment $(2 \mathrm{mM}$ and $4 \mathrm{mM})$ and the control plants. The lowest amount of soluble sugar was observed in spermidine treatment (at $2 \mathrm{mM}$ concentration) and the highest amount was obtained from plants treated with $2 \mathrm{mM}$ and $4 \mathrm{mM}$ of putrescine. However, the other polyamine treatments (putrescine $1 \mathrm{mM}$, spermidine $1 \mathrm{mM}, 2 \mathrm{mM}$ and $4 \mathrm{mM}$ and spermine $1 \mathrm{mM}, 2 \mathrm{mM}$ and $4 \mathrm{mM}$ ) did not remarkably change in comparison with the control plants (see Figure 4).

Reasons for increasing the content of soluble sugars include increasing the amount of photosynthetic pigments, leaf area and number of leaves, increasing the photosynthetic capacity and protecting macromolecules such as proteins and cell membranes (Savvas and Ntatsi, 2015). The stimulating effect of amino acids on carbohydrate content is probably due to their essential role in the biosynthesis of chlorophyll molecules that affect chlorophyll content (Nahed et al., 2009). In this study, considering the effect of polyamines on leaf area, leaf number and photosynthetic pigments, it can be inferred that polyamines enhance the photosynthetic capacity and consequently increase the soluble sugar content.

The results of the present study are consistent with the results of studies on Calendula officinalis (Bani-Assadi et al., 2015), Gladiolus (Nahed et al., 2009), Celosia argentea (Badawy et al., 2015b) and Salvia splendens (Kandil et al., 2015), in which the amount of soluble sugar was increased by increasing the concentration of polyamines.

In this study, polyamine treatment did not increase leaf anthocyanin compared to the control (Figure 5). The highest anthocyanin level was observed in spermidine treatment with the concentration of $4 \mathrm{mM}$; however, the results did not go far from the control plant and the lowest level was related to the putrescine treatment with the concentration of $2 \mathrm{mM}$. As presented in Figure 6, there was no increase in phenol content of the treated plants as compared to the control plants. The highest amount of phenol was related to the control plants, and the lowest amount was obtained from those plants that were treated with $2 \mathrm{mM}$ of spermidine and spermine. The highest antioxidant capacity of the leaves belongs to the control plants, and the minimum antioxidant capacity was related to the treatment of spermine at the concentration of $2 \mathrm{mM}$ (see Figure 7). Polyamine treatment at none of the concentrations could increase

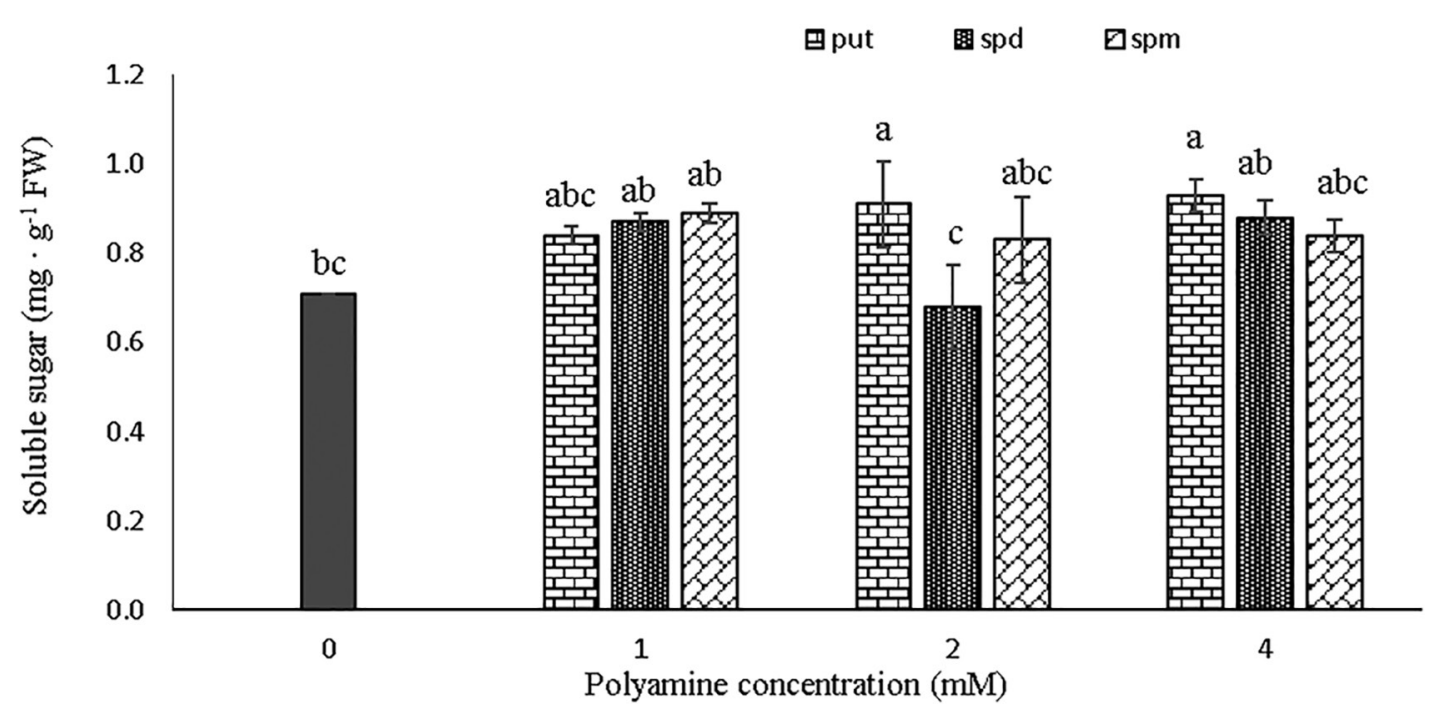

Figure 4. The effect of polyamine concentration on soluble sugar of rose 'Herbert Stevens'. Values followed by the same letter(s) do not differ significantly at $p=0.01$. 


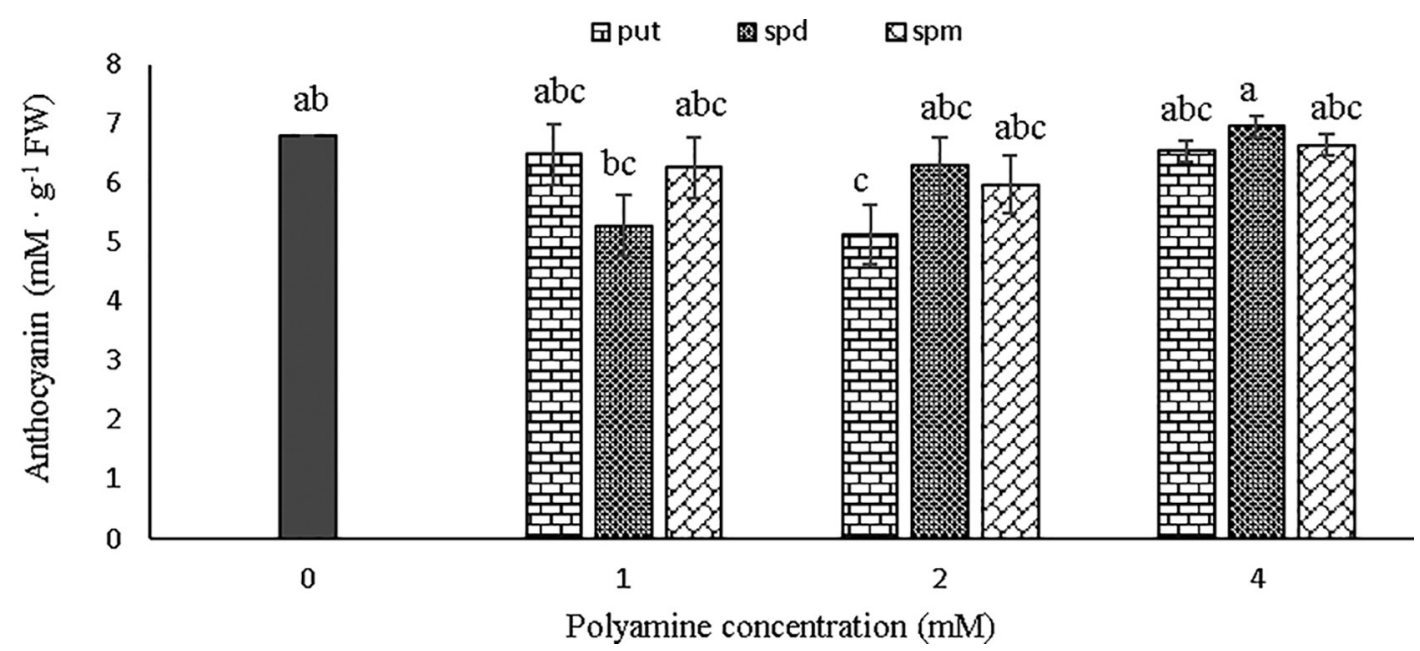

Figure 5. The effect of polyamine concentration on anthocyanin of rose 'Herbert Stevens'. Values followed by the same letter(s) do not differ significantly at $p=0.05$.

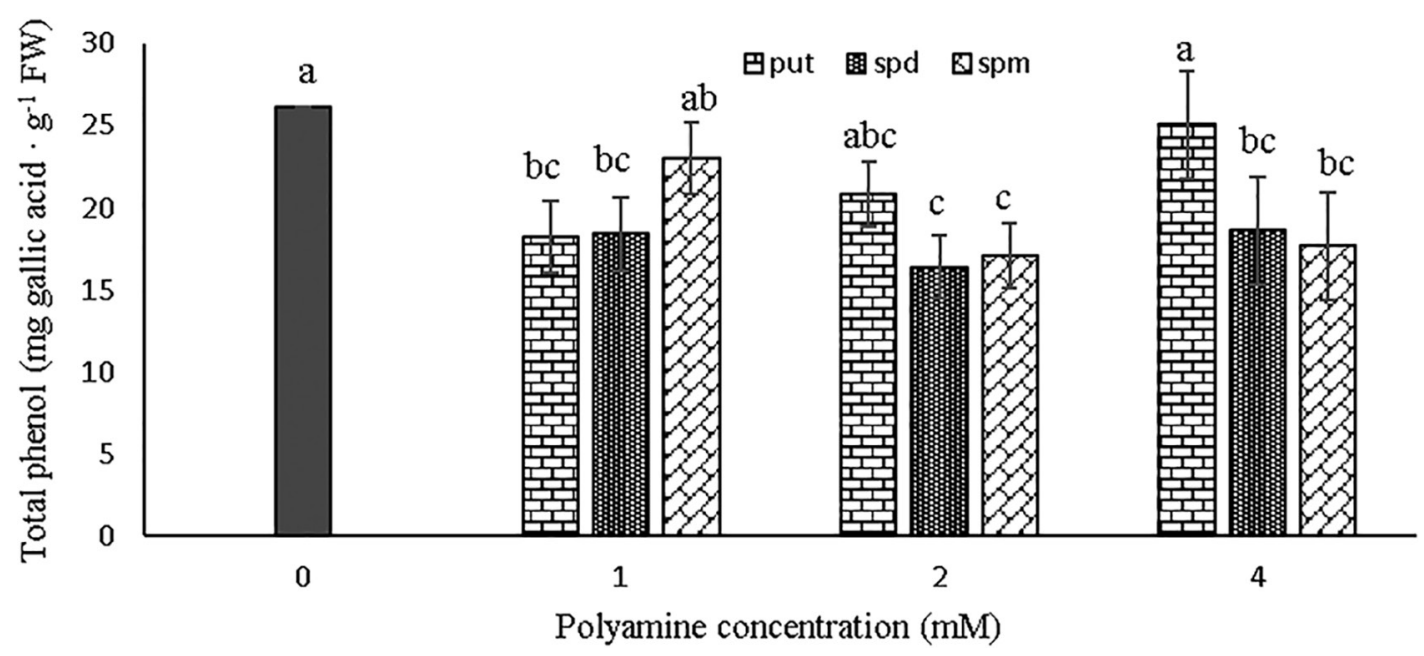

Figure 6. The interactive effect of type and concentration of polyamine on total phenol of rose 'Herbert Stevens'. Values followed by the same letter(s) do not differ significantly at $p=0.01$.

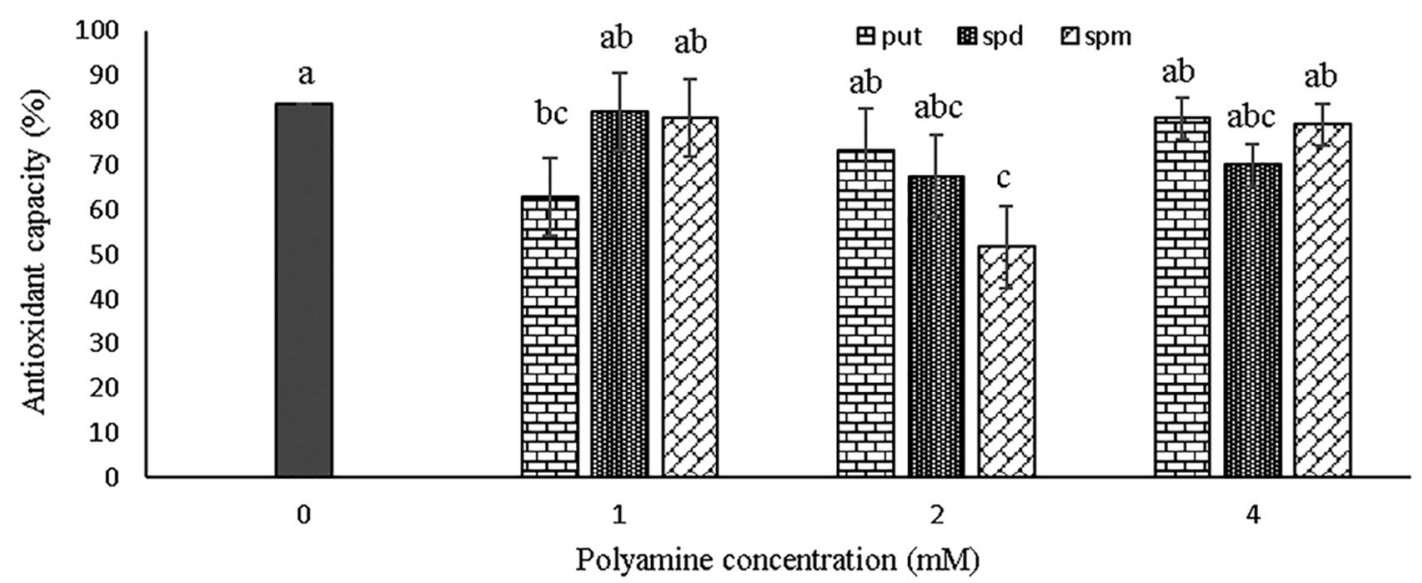

Figure 7. The interactive effect of type and concentration of polyamine on antioxidant capacity of rose 'Herbert Stevens'. Values followed by the same letter(s) do not differ significantly at $p=0.01$. 
the antioxidant capacity as compared to the control plants (see Figure 7).

In plants, anthocyanin production is affected by various factors such as light, temperature, carbohydrates, plant hormones and stress. These factors affect the level of anthocyanin mainly by influencing transcription factors (Kim et al., 2006). Studies on various plants have shown that nitrogen restriction affects the synthesis of anthocyanins and phenols. Nitrogen can reduce the production of secondary metabolites by reducing the activity of phenylalanine ammonia-lyase (PAL), which is associated with $\mathrm{N} / \mathrm{C}$ ratio, photosynthesis and total unstructured carbohydrate (Ibrahim and Jaafar, 2011; Ibrahim et al., 2012; Larbat et al., 2012; Soubeyrand et al., 2014). The rather high concentration of polyamines in plant cells is indicative of their possible importance as a nitrogen source. A study on explants from the Jerusalem artichoke tubers showed that putrescine and spermidine could be a replacement for inorganic nitrogen that is used to promote growth (Takahashi, 2020). With the increase in auxins, anthocyanin synthesis is blocked more intensely. Auxin alone reduced the transcription of anthocyanin regulation genes. On the other hand, the results showed that nitrogen deficiency could increase the synthesis of anthocyanins inhibited by auxins (Ji et al., 2014). In considering the effects of nitrogen and auxin on the synthesis of anthocyanins and the fact that polyamines are compounds that contain nitrogen in their structure, we hypothesise that these factors play a role in the balance of the N/C ratio and have a direct relationship with auxins, since it can be said that they may affect the content of anthocyanins, phenol and antioxidant capacity.

Antioxidants in oxidative stress conditions can prevent oxidative damage by inactivating reactive oxygen species. Phenols are a group of secondary metabolites with antioxidant properties that are present in all plants. Flavonoids are a well-known group of phenolic compounds. Anthocyanins are also a group of phenolic compounds with antioxidant properties. PAL is the major enzyme involved in the metabolism of phenol, which increases its synthesis and activity under stress (Hudec et al., 2007). In an experiment, O-phosphoethanolamine (KF), which inhibits ornithine decarboxylase, was used to increase phenolic levels and antioxidant capacity of the studied plants. Ornithine decarboxylase is one of the important enzymes in the biosynthesis of polyamines. In this study, the use of $\mathrm{KF}$ affected and increased the antioxidant capacity, phenolic content and amount of anthocyanins in leaves. $\mathrm{KF}$ inhibits the synthesis of polyamines, including putrescine and spermidine, so that phenolic compounds cannot bind to polyamines and remain unconjugated; therefore, this inhibition of polyamines leads to higher antioxidant activity (Hudec et al., 2007). Polyamines can make conjugation with phenolic compounds, affect their polarity and hydrophilicity and so promote their translocation, compartmentation and stability
(Mustafavi et al., 2018). The results of this study were in agreement with the results of studies on tobacco and wheat; these studies reported that exogenous putrescine reduced the phenol content. However, spermidine treatment in these studies led to an increase in phenol, which is believed to be due to spermidine growth retardation (Rahdari and Hoseini, 2013). In contrast with these results, in a study on Gladiolus, Nahed et al. (2009) noted that application of putrescine increased phenol content in plant.

It is believed that plant antioxidants play a protective role against various diseases and delay senescence processes. Compounds, such as polyphenols, vitamin C, anthocyanins, and flavonoids, have antioxidant properties (Ibrahim et al., 2012). Polyamines have antioxidant properties too (Aronova et al., 2005). The antioxidant effect of polyamines depends on the number of amino groups in their molecules; thus, spermine has a higher antioxidant effect than spermidine, and the antioxidant activity of spermine is higher than that of putrescine. Similar to antioxidants, polyamines also protect membrane lipids against oxidative damage, and therefore maintain the hemostasis of the plant cells (Aronova et al., 2005). Higher antioxidant activity can be attributed to an increase in total phenolic compounds. There seems to be a linear relationship between antioxidant activity and phenolic compounds, which has been reported in many plants (Razzaq et al., 2014). Phenols and anthocyanins are compounds with antioxidant properties, and the increase in their amount leads to a rise in antioxidant capacity. Under stress conditions, the amount of antioxidant activity and compounds with antioxidant properties increases, to protect the plant. In non-stress conditions, as mentioned earlier, polyamines do not increase antioxidant compounds but create a balanced environment for the plant. Considering that the current study was performed in a non-stress condition, it was observed that polyamine treatments (putrescine, spermidine and spermine) in specified concentrations ( $1 \mathrm{mM}, 2 \mathrm{mM}$ and $4 \mathrm{mM}$ ) could not result in a considerable increase in the anthocyanins, total phenol and antioxidant capacity compared to the control plants.

\section{CONCLUSIONS}

In general, it can be concluded that the application of polyamines can remarkably influence the growth characteristics of plants in various ways. Among three polyamines, putrescine (especially $1 \mathrm{mM}$ ) was most effective in morphological parameters. In the present study, application of polyamines has a similar effect on antioxidant capacity, phenol and anthocyanin levels, of which the highest levels were observed in the control plants.

\section{FUNDING}

The authors received no specific funding for this study. 


\section{AUTHOR CONTRIBUTIONS}

All authors contributed equally to the research involved in this study and drafting of the manuscript.

\section{CONFLICT OF INTEREST}

Authors declare that no competing interests exist.

\section{REFERENCES}

Alborz, Z., Habibi, F., and Mortazavi, S. N. (2015). The effect of putrescine and spermine spraying on increasing vase life of Alstroemeria cv. Sukari. Journal of Crops Improvement (Journal of Agriculture), 17(1), 241-255.

Alcazar, R., Altabella, T., Bortolotti, C., Carrasco, P., Koncz, C., Marco, F., Reymond, M., And Tiburcio, A. F. (2010). Polyamines: Molecules with regulatory functions in plant abiotic stress tolerance. Planta, 231, 1237-1249.

Amorim, T. L., De Medeiros, D. C., De Oliveira, A.A.S., Paes, R.A., Junior, W.S.E., and Moreira, D.A. (2017). Gibberellin and polyamines in plant growth, development, and postharvest senescence of ornamental plants. Amazonian Journal of Plant Research, 1, 1-13.

Anwar, R., Mattoo, A. K., And Handa, A. K. (2015). Polyamine interactions with plant hormones: Crosstalk at several levels. In T. Kusano and H. Suzuki (Eds), Polyamines (pp. 267-304). Japan: Springer.

Aronova, E. E., Shevyakova, N. I., Stetsenko, L.A., And Kuznetsov, V.V. (2005). Cadaverine-induced ibduction of superoxide dismutase gene expression in Mesembryanthemum crystallinum L. Doklady Biological Sciences, 403(1), 257-259.

Ashari, A., Zakaei, M., and Khosroshahi, M. R. (2008). Polyamines and horticultural sciences. Iran: Bu-Ali Sina University Press (in Persian).

Badawy, E. M., Kandil, M. M., Habib, A. M., And El-SAYED, I.M. (2015a). Influence of diatomite, putrescine and alpha-tocopherol on some vegetative growth and flowering of Antirrhinum majus L. plants. Journal of Horticultural Science \& Ornamental Plants, 7(1), 7-18.

Badawy, E. M., Kandil, M. M., Mahgoub, M., Shanan, N., ANd Hegazi, N. (2015b). Chemical constituents of Celosia argentea var. cristata L. plants as affected by foliar application of putrescine and alpha-tocopherol. International Journal of ChemTech Research, 8(12), 464-470.

Baniasadi, F., Safari, V. R., And Moud, A. M. (2015). Effect of putrescine and salinity on the morphological, biochemical, and pigments of English marigold plant (Calendula officinalis L.). Journal of Science and Technology of Greenhouse Culture, 6(21), 125-133, (in Persian).

Bhattacharjee, S. K., And BanerJi, B. K. (2010). The complete book of roses. Jaipur, India: Aaviskar.
Chen, D., ShaO, Q., Yin, L., Younis, A., And Zheng, B. (2019). Polyamine function in plants: Metabolism, regulation on development, and roles in abiotic stress responses. Frontiers in Plant Science, 9, 1945, doi: 10.3389/fpls.2018.01945.

Dastyaran, M., Hosseini Farahi, M. (2014). The effect of humic acid and putrescin on vegetative properties and vase life of rose in a soilless system. Journal of Soil and Plant Interactions, 5(4), 241-250 (in Persian).

El-Quesni, F. E. M., Kandil, M. M., And Mahgoub, M. H. (2007). Some studies on the effect of putrescine and paclobutrazol on the growth and chemical composition of Bougainvillea glabra L. at Nubia. American-Eurasian Journal of Agricultural \& Environmental Sciences, 2(5), 552-558.

Espin, J. C., Soler-Rivas, C., AND Wichers, H. J. (2000). Characterization of the total free radical scavenger capacity of vegetable oils and oil fractions using 2, 2-diphenyl-2-picrylhydrazyl radical. Journal of Agricultural and Food Chemistry, 48, 648-656.

Habba, E. E., Abdel Aziz, N. G., Sarhan, A. M. Z., Arafa, A. M. S., AND Youssefi, N. M. (2016). Effect of putrescine and growing media on vegetative growth and chemical constituents of Populus euramericana plants. Journal of Innovations in Pharmaceutical and Biological Sciences, 3(1), 61-73.

Hudec, J., BurdovaA, M., Kobida, L., Komora, L., Macho, V., Kogan, G., Turianica, I., Kochanovaa, R., Lozyek, O., Habaan, M., and Chlebo, P. (2007). Antioxidant capacity changes and phenolic profile of Echinacea purpurea, nettle (Urtica dioica L.), and dandelion (Taraxacum officinale) after application of polyamine and phenolic biosynthesis regulators. Journal of Agricultural and Food Chemistry, 55, 5689-5696.

IBrahim, M. H., AND JAAFAR, H. Z. E. (2011). Effects of nitrogen fertilization on synthesis of primary and secondary metabolites in three varieties of kacip fatimah (Labisia pumila Blume). International Journal of Molecular Sciences, 12(8), 5238-5254.

Ibrahim, M. H., JaAfar, H. Z. E., RAhmat, A., AND ABdul Rahman, Z. (2012). Involvement of nitrogen on flavonoids, glutathione, anthocyanin, ascorbic acid and antioxidant activities of Malaysian medicinal plant Labisia pumila Blume. International Journal of Molecular Sciences, 13(1), 393-408.

Irigoyen, J. J., Emerich, D. W., and SAnchez-Diaz, M. (1992). Water stress-induced changes in concentrations of proline and total soluble sugars in nodulated alfalfa (Medicago sativa) plants. Plant Physiology, 84(1), 55-60.

Ji, X. H., Wang, Y. T., Zhang, R., Wu, S. J., An, M. M., Li, M., WAng, C. Z., Chen, X. L., Zhang, Y. M., AND Chen, X. S. (2014). Effect of auxin, cytokinin and nitrogen on anthocyanin biosynthesis in callus cultures of redfleshed apple (Malus sieversii $f$. niedzwetzkyana). Plant Cell, Tissue and Organ Culture, 120(1), 325-337. 
Kandil, M. M., Ibrahim, M. M., El-Hanafy, S. H., And El-Sabwah, M. M. (2015). Effect of putrescine and uniconazole on some flowering characteristics and some chemical constituent of Salvia splendens F. plant. International Journal of ChemTech Research, 8(9), 174-186.

Kim, J. S., LeE, B. H., KIM, S. H., OK, K. H., AND ChO, K. Y. (2006). Response to environmental and chemical signals for anthocyanin biosynthesis in nonchlorophyllous corn (Zea mays L.) leaf. Journal of Plant Biology, 49(1), 16-25.

Kusano, T., And Suzuki, H. (2015). Polyamines. Japan: Springer.

Larbat, R., Olsen, K. M., Slimestad, R., Lovdal, T., Benard, C., Verheul, M., Bourgaud, F., Robin, C., AND LiLlo, C. (2012). Influence of repeated short-term nitrogen limitations on leaf phenolics metabolism in tomato. Phytochemistry, 77, 119-128.

Mahgoub, M., El Aziz, N. G. A., And Mazhar, A. M. A. (2011). Response of Dahlia pinnata L. plant to foliar spray with putrescine and thiamine on growth, flowering and photosynthetic pigments. American-Eurasian Journal of Agricultural \& Environmental Sciences, 10(5), 769-775.

Marinova, D., Ribarova, F., and Atanassova, M. (2005). Total phenolics and total flavonoids in Bulgarian fruits and vegetables. Journal of the University of Chemical Technology and Metallurgy, 40(3), 255-260.

Mustafavi, S. H., Badi, H. N., Sekara, A., Mehrafarin, A., Janda, T., Ghorbanpur, M., And Rafiee, H. (2018). Polyamines and their possible mechanisms involved in plant physiological processes and elicitation of secondary metabolites. Acta Physiologiae Plantarum, 40(6), 1-19.

Nahed, G. A. A, Lobna, S. T., And Soad, M. I. (2009). Some studies on the effect of putrescine, ascorbic acid and thiamine on growth, flowering, and some chemical constituent of Gladiolus plants at Nuberia. Ozean. Journal of Applied Science, 2(2), 169-179.
Pegg, A. E., And Michael, A. J. (2010). Spermine synthase. Cellular and Molecular Life Sciences, 67(1), 113-121.

Rahadari, P., And Hoseini, S. M. (2013). Roll of polyamines (spermidine and putrescine) on protein, chlorophyll and phenolic compounds in wheat (Triticum aestivum L.) under salinity stress. Journal of Novel Applied Sciences, 2(12), 746-751.

Razzaq, K., Khan, A. S., Malik, A. U., Shahid, M., and Ullaha, S. (2014). Role of putrescine in regulating fruit softening and antioxidative enzyme system in 'Samar Bahisht Chaunsa' mango. Postharvest Biology and Technology, 96, 23-32.

Savvas, D., And NTATsi, G. (2015). Biostimulant activity of silicon in horticulture. Scientia Horticulturae, 196, 66-81.

Soubeyrand, E., Basteau, C., Hilbert, G., Leeuwen, C., Delrot, S., And Gomes, E. (2014). Nitrogen supply affects anthocyanin biosynthetic and regulatory genes in grapevine cv. Cabernet-Sauvignon berries. Phytochemistry, 103, 38-49.

Tajti, J., Hamow, K. A., Majlath, I., GiercziK, K., Nemeth, E., JAndA, T., And PaL, M. (2019). Polyamineinduced hormonal changes in eds5 and sid2 mutant Arabidopsis plants. International Journal of Molecular Sciences, 20(22), 5746, doi: 10.3390/ ijms20225746.

Takahashi, T. (2020). Plant polyamines. Plants (Basel), 9(4), 511, doi: 10.3390/plants9040511.

WAGNER, G. J. (1979). Content and vacuole/extra vacuole distribution of neutral sugars, free amino acids and anthocyanin in protoplasts. Plant Physiology, 64(1), 88-93.

Wang, W., Paschalidis, K., Feng, J. C., Song, J., Liu, J. H. (2019). Polyamine catabolism in plants: A universal process with diverse functions. Frontiers in Plant Science, 10, 561, doi: 10.3389/fpls.2019.00561.

Received: July 6, 2020; accepted: January 3, 2021 